\title{
Assessment of different seedling production techniques of Euterpe edulis
}

\author{
Leonardo Lima Pereira Regnier ${ }^{*}$, Maria Luiza Faria Salatino ${ }^{1}$ \\ 'Departamento de botânica -Instituto de Biociências- Universidade de São Paulo - R. do Matão, 187 \\ - Butantã, São Paulo - SP, 05508-09036036-900, Brazil \\ *regnier@alumni.usp.br
}

\begin{abstract}
Euterpe edulis is an endangered species with high importance ecologically and economically. Seedling production seems to be one of the most important alternatives to population recovery. Besides that, the knowledge of seedling production methods' influence over germination is very restricted. Thus, this study aimed to evaluate the effects of parent populations, germination conditions, and the substrate to commercial seedling production of $E$. edulis. Nine thousand seven hundred and thirteen seeds were distributed between the heated water and control, greenhouse and open-field treatments. The parent population presented high differences between most of the germination indexes. Influencing the germination rate, mean germination time and germination speed, but not affecting synchrony and uncertainty indexes. Heated water treatment did not affect any of the studied indexes, presenting a close pattern of germination over time, indicating it is an appropriate method for seedling production. Greenhouse and open-field treatment presented variations at the same indexes affected in the parent population analysis. The most profitable method for $E$. edulis seed germination was the greenhouse production method, which provided the best indexes results.
\end{abstract}

Keywords: Palmiteiro; Forestry seeds; Seed development; Arecaceae;

Germination

\section{INTRODUCTION}

Euterpe edulis Mart. also known as Palmiteiro, is one of the most representative and explored species from the Tropical Atlantic Rainforest [1]-[3], and is considered one of the most important [4]. Its slim, cylindrical, and straight stipe with a great green sheath is easily recognizable [1]. This species presents low and slow germination due to the mechanical structure of the seeds. These are recalcitrant; thus, they are not resistant to dry and/or temperature reduction. These features contribute to its longterm life cycle [5], [6]. Seedling growth seems to be limited by light exposure in natural conditions [7]. Adult individuals only reach sexual maturity between six and nine years old. These characteristics also hamper the natural regeneration of its populations. 
This species also plays a relevant ecologic role as a food source for a great number of animals like birds, mammals, and insects [6], [8]. These interactions contribute to the reduced number of viable seeds that stay disposable to germinate and recover the population. An even lower number of germinated seeds reaches one-yearold [6].

The economic relevance of this species is its use as the heart of palm (the youngest part of the stipe, apical meristem, and young leaves) source. The heart of palm from this species presents high economic value and is an important product in the Brazilian and international markets [3], [4], [8], [9]. Besides, this species does not present tillers from the stipe basis [4]. Thus, harvesting the heart of palm from $E$. edulis implicates in the individual's death. Furthermore, the illegal harvesting of this species heart of palm has been focusing on individuals at least 2 meters high. This criterion not only affects young individuals but also those in the reproductive phase (between six- and nine-year-old individuals), which is incompatible with this species slow life cycle, leading to a reduction in the natural populations and extinction [1], [4], [9].

$E$. edulis is also a key species in ecologic studies of the Atlantic rainforest [9]. Other authors have demonstrated that programs seeking in situ recovery must focus on seed banks' maintenance and replanting techniques to effective forestry management [2], [5]. Thus, scientific research development in seedling production and ecophysiology is essential to guide recovery programs and/or commercial production [4], [5], [7], [10].
The demand for reproduction, quality, seed conservation, and seedling production technologies has been growing due to recovery programs and the recent inclusion of $E$. edulis species in landscaping projects [11]. Seedling production has also been pointed out as the main method for the management of natural populations of E. edulis [4], [12]. However, this knowledge is still very limited. Only recently, two basic aspects, how the removal of the mesocarp and light exposure influences over germination has been recognized [13]. The lack of technologies and knowledge in the exploration of native forestry resources [8] associated with natural habitat destruction are the main causes that still have been taken the native species to decline [8], [9].

In general, parent plants seem to influence the seedling quality and germination rate of its seeds [12], [14]. Most recently, to $E$. edulis, great diversity has been discovered and better explored [9], [15]-[17]. Besides that, the comprehension of how these differences between populations could affect germination parameters is not adequately known [9]. This aspect could provide important information in seedling production since the choice of a progenitor population used as seed sources could affect seedling production [12], [14].

The mechanical structure of this species seeds seems to hinder water penetration, generating great variations between seed germination rate [6]. One possible method to overcome this is by using hot water [18], [19], which also makes the removal of fruit pulp easier [5]. However, this method could reduce seed viability and reduce germination. Previous studies 
concerning the impact of hot water treatment on mineral bioaccessibility have already been conducted [20]. Nevertheless, possible germinations effects of this technique have not been extensively recognized in the literature.

In order to promote germination, in the commercial seedling production context, there are two main processes, open-field germination, where seeds are directly exposed to environmental conditions such as sunlight and temperature, or germination in a greenhouse, where seeds are exposed to greater temperature and moisture but less sunlight than the production area [21], [22]. These different techniques could also impact seed germination and seedling persistence [23], and aspects that have not yet been explored to E. edulis.

Therefore, due to the high ecological and economic importance associated with the great demand for reproductive techniques of this species. This study aimed to evaluate the effects of parent populations, heated water processing, and the open-field production approach to commercial seedling production of $E$. edulis.

\section{MATERIAL AND METHODS}

This study was conducted at the Harry Blossfeld plant nursery of São Paulo, situated in Cotia (2336'30.0"S 4650'48.9"W). According to Köppen's climate classification, the study region presents Cwa, the altitude tropical climate [24]. Featuring concentered rains during summer, dry winter, and the highest mean temperature above $22^{\circ} \mathrm{C}$.

Plant material was collected in the western region of São Paulo in July and August 2018. Population I is 24 km distant from populations II and III, and these last two were $1 \mathrm{~km}$ away from each other. Fruits were gathered directly from the treetop and fallen fruits were also collected. All materials were kept in open plastic bags at room temperature for 2 days during the processing stage.

The study was divided into three steps. First, seeking to evaluate the parent population influence, approximately one thousand seeds from each of the three different populations were evenly distributed between two repetitions of the standard treatment [25]. This treatment consisted of exocarp and mesocarp removal with a sieve and running tap water. Seeds were planted in white trays containing vermiculite as a substrate and kept in a greenhouse with white plastic covering and a fogging watering system with periodic activation every $35 \mathrm{~min}$.

The second part consisted of six thousand seeds, from population I, divided between two replicas of the 2 treatments. The control treatment used was the same as the standard treatment used in the first part of the study. While in the second treatment, all fruits were previously submerged in the heated water at $80^{\circ} \mathrm{C}$, seeking to facilitate the exocarp and mesocarp removal with a sieve and tap water. In sequence, seeds were planted in an open-field plant bed containing vermiculite as a substrate without any kind of covering and irrigation two times daily.

Seeking to evaluate seed development in open fields, 1000 fruits from the same population, submitted to the standard treatment, and planted as described in the second part were sowed in plant beds containing 
vermiculite as substrate without any kind of covering and irrigation two times daily, 8 am and 4 pm.

Plant emergence was recorded 134 days after seeding, with measurements nearly every 7 days.

The evaluation consisted of the use of indexes as mean germination time, or mean length of incubation time [26], and the standard deviation was calculated as proposed by Haberlandt in 1875 [27]. All other indexes were calculated as presented by Lozano-Isla et al. [28].

All data were compiled into the Excel component of the Microsoft Corporation Office pack and represented through graphics and tables. The most common germination indices were obtained using GerminaQuant software [28]. All statistical tests were executed with individual data of the replicas and performed using GerminaQuant, based on $\mathrm{R}$ software [29]. The results were tested by ANOVA and in sequence submitted to the Tukey test, adopting a critical $p$-value of $1 \%(\alpha<0.01)$.

\section{RESULTS AND DISCUSSION}

\section{Parent population}

The parent population seems to influence the Germination proportion (GRP), Mean germination rate (MGR), and Germination speed (GSP) (Fig. 1A, 1B, 1D). While Uncertainty (UNC) and Synchrony (SYN) indexes were not different (Fig. 1E, 1F). Populations I and II presented the highest germination rates $(91.3 \%$ and $78.57 \%)$ and were consistently different from population III (22.9\%). The mean germination rate index (MGR) indicates, in this study, the frequency of germinations, as the mean germinations/day. Thus, it is the reciprocal information of mean germination time (MGT) [26]. 
A

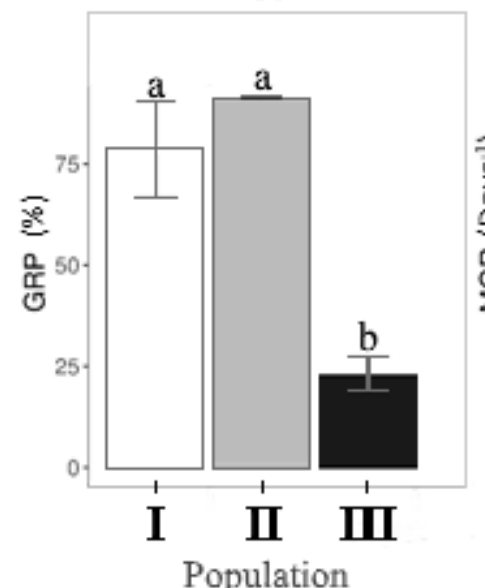

Population

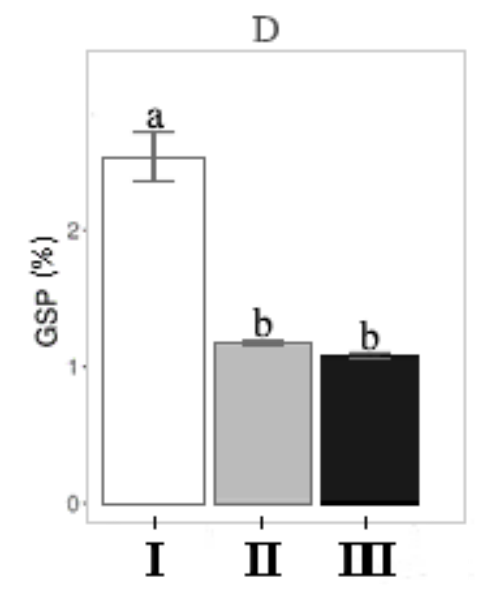

Population
B

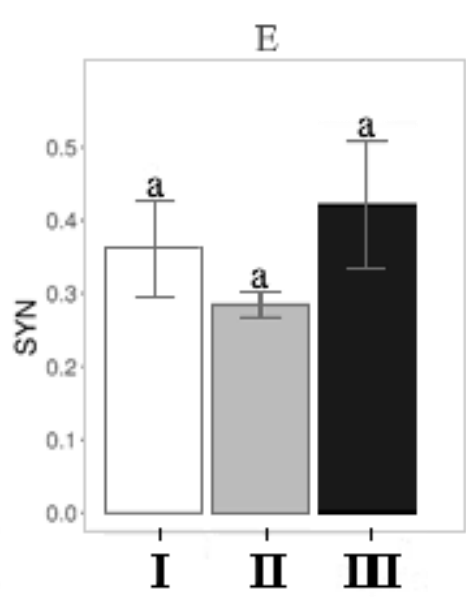

Population
$\mathrm{C}$

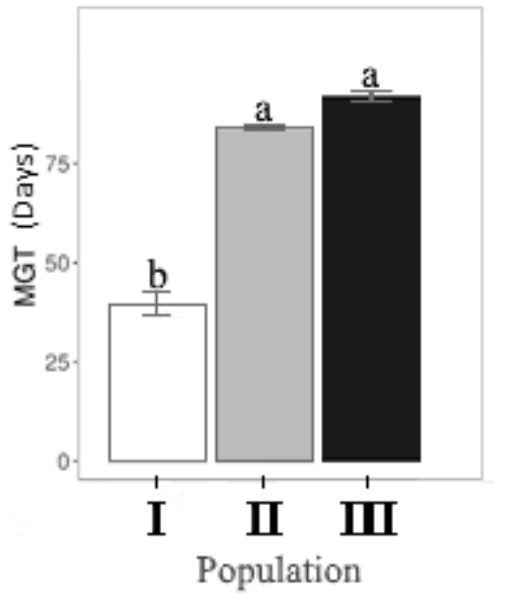

$\mathrm{F}$

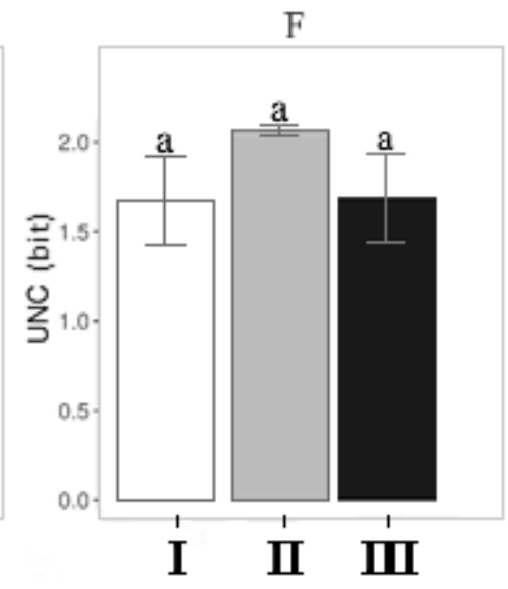

Population

Figure 1. E. edulis germination indexes according to seed population origin (I, II, III). A - Germination Proportion (GRP), B - Mean germination rate (MGR), C Mean germination time (MGT), D - Germination speed (GSP), E - Synchronization index (SYN), and F - Uncertainty index (UNC). Lowercase letters present statistical differences using $p<0.01$. Error bars represent the standard error mean.

The mean germination time (MGT) or mean length of germination time demonstrates the required time for one seed of some species to germinate [26], [30]. It is an important index insofar as it demonstrates the mean expected time for most seeds of a seed lot to germinate. Therefore, it is possible to estimate the necessary time for some specific culture to grow properly. The data between the populations were significantly different (Fig. 1). Only populations II and III presented similar mean germination rates (84.36 and 91.9, respectively). Population I reached stabilization about half the time obtained by the other populations, and also greater germination speed in this study (Fig. 1D). These are a valuable aspect of the seedling production context. Thus, population I has the most profitable offspring, seeking better production. 
Mean germination time is associated with the general characteristics of the seed species, seed lot quality, and environmental conditions [5], [31]. The unbridled harvesting of adult individuals that led E. edulis natural population decline, related to the reproduction between related individuals, could have led some populations to less vigorous offspring, a process called endogamy depression [12], which directly affects seed quality [2], [14]. This species presents an aggregated spatial distribution of seedlings, favoring intraspecific competition and greater vulnerability to diseases and plagues [32]. These features, associated with short distance gene flow [14], could result in high endogamy, reducing seed diversity and quality. This process directly impacts the seed harvesting approach seeking conservation projects [14], since the great variation between seed lots hampers commercial seedling production [12]. The studied parental populations had considerable variations in germination rate and also germination speed indices (Fig. 1). Indicating that choosing some population offspring not only influences the exploitation of a seed lot, based on the germination proportion, but also on the time required for seedling emergence. Thus, the process of choosing a parental population for seedling production seems to be a very important aspect to be considered.
The germination rates of the studied parent populations provided significant differences between population III and the others (Fig. 1A). The cumulative germination course also reveals the discrepant performance of this population compared to the others (Fig. 2). Germination of $E$. edulis seems to differ greatly due to genetic variations between fruits, even when they are harvested at the same time and present the same developmental stages [12]. An important aspect of genetic variability in the reproductive system [14]. It is estimated that the gene flow between individuals of $E$. edulis is 56 meters using DNA markers [14], which favors genetic isolation between populations and high variations between them [9]. However, natural population decline seems to have led to endogamy depression. Parent plant age also seems to influence the germination indices [3], [6], and the reproductive season [2]. Germination presented in other studies comprehends the range of $16 \%$ to $52 \%$ at 12 days after sowing [6] and from $44 \%$ to $73 \%$ between 100 and 150 days after seeding [12], [33]. The present study data indicate a higher germination rate in populations I and II than those previously mentioned values found by those authors (Fig. 2). Besides that, none of the studied populations reached at least $16 \%$ of germination during the first 12 days after sowing, as mentioned by Bovi [6]. However, these discrepancies 
are common between non- presented a great diversity of domesticated species [14] due to germination responses between the genetic variations, and also the populations. Corroborating this environmental conditions related to the locations were the studies were performed.

It is important to note that the germination pattern was very different between the populations (Fig. 2). Although populations I and II reached relatively close germination results at the end of the study period, their trajectory until reach those results were not equal. Most recent studies have shown that, in general, diversity between this species' populations remains high considering fragmentation, habitat destruction, and selective information, conspicuous variations between germination indexes were observed when comparing populations of $E$. edulis.

In commercial seedling production, understanding the factors that could impact seed lot quality is very important, especially for understanding suboptimal results [34]. These study data indicate that choosing the parental population as a seed lot provider could drastically modify seed lot quality, being a crucial aspect in the seedling production context.

exploration [9]. Our results also

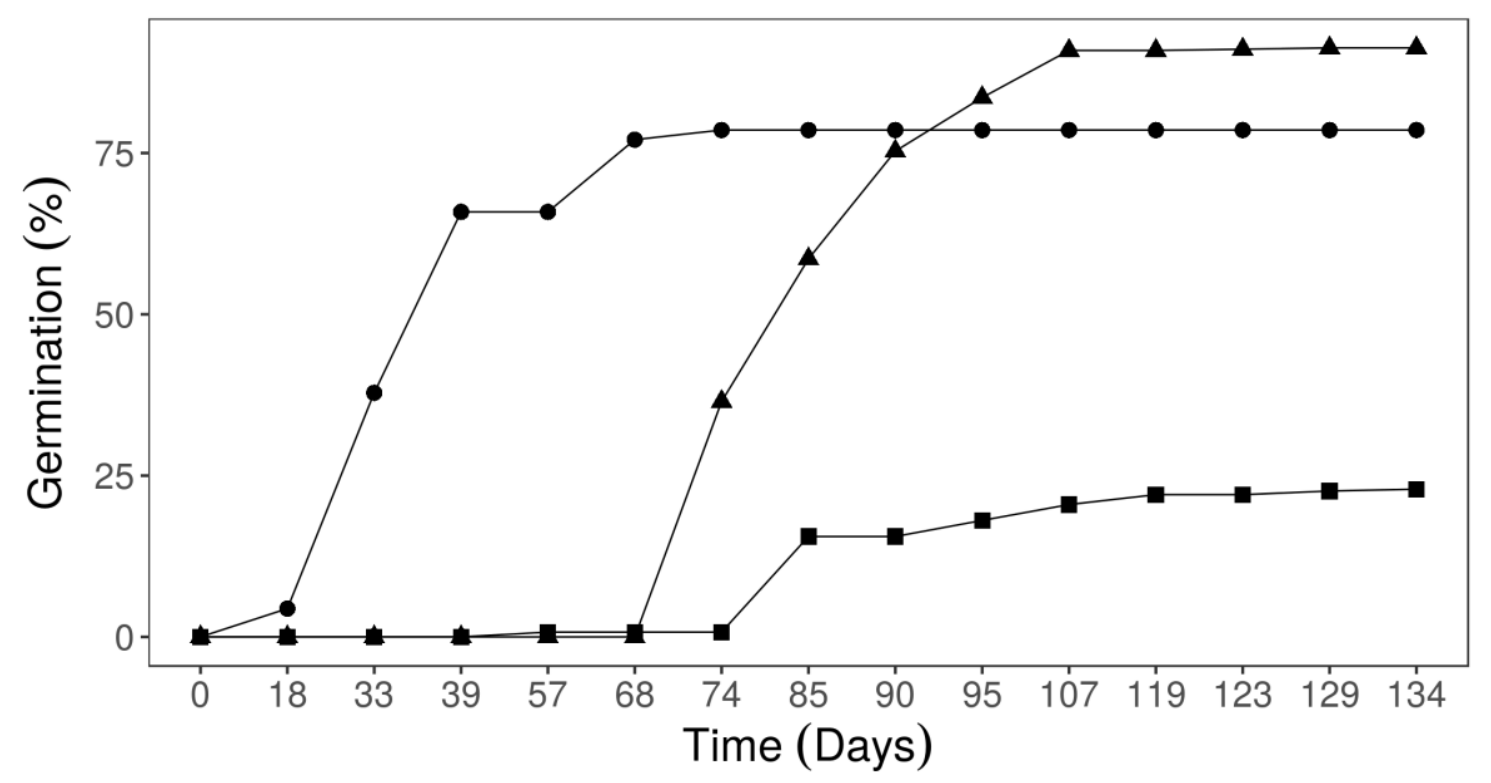

Figure 2. Cumulative germination of E. edulis according to seed origin: Population I (•), Population II ( $\boldsymbol{\Delta})$, and Population III ( $\mathbf{\square}$ ).

Non-cumulative germination pattern indicates that, in general, germinations are concentrated at some specific period, when most of the seeds geminate synchronically
(Fig. 3). Besides that, the values of the germination rate reached by each population varies. The population III pattern is similar to other populations but delayed and 
with lower values (Fig. 3). Noncumulative germination analysis could provide some important information. In this study, seeds from different populations seem to exhibit a similar pattern, with relatively concentrated germinations at some specific time, diverging only by when this higher emergence period happens. This fact explains why the uncertainty and synchrony indexes were similar between the studied populations (Fig. 1). Insofar as they presented a very similar distribution pattern but with contrasts about the time required to reach great germination occurrence. The different parent populations seem to provide variations on when germination occurs and the relative distribution of germination all over time.
Although, it is important to note the long-term germinations presented by this species. Previously, other authors have already mentioned that the greater variations in the required time to seedling emergence is an adaptive strategy required to maintain a proper seed bank [12]. An essential implication of ecologic dynamics because if all the seeds from a single cohort present unsynchronized and long-term emergence, this single reproduction event could provide recruits to the population during very long periods, even with dramatic reductions in the parental population. However, these features hamper seedling production [35] because this context only favors faster and synchronized germinations.

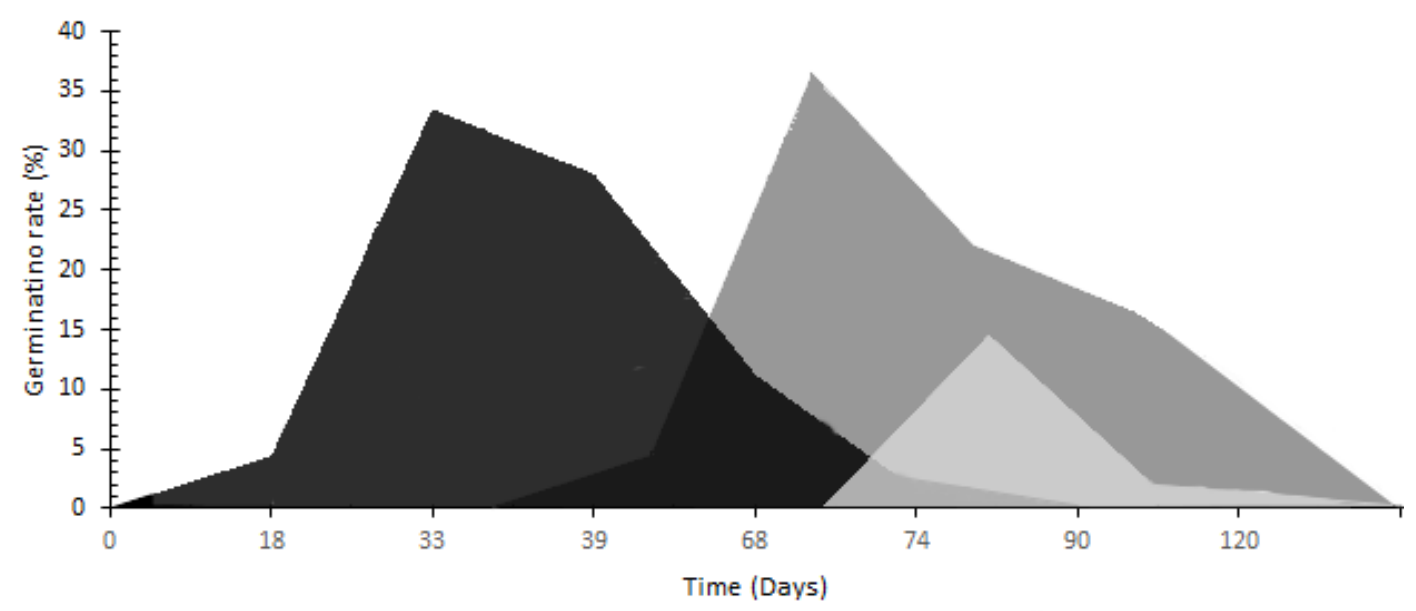

Figure 3. Non-cumulative germination of E. edulis according to seed origin: Population I ( $\square$ ), Population II ( $\square$ ), and Population III ( $)^{\text {). }}$

\section{Heated water treatment}

There was no difference between the control and heated water treatments. All the analyzed indexes did not present significant variations. It seems that using heated water only provides a slight 
reduction in germination proportion and mean germination time (Fig 4). In general, heated water promotes mechanical ruptures that can easily lead water to permeate [36]. However, high temperatures could also kill the embryos, reducing seed viability [5]. Our results show that any of the studied indexes related to the time required for germination, speed, or germination rate were substantially affected by this method at this study parameters. Indicating that there is no significant reduction in seed viability when exposed to this temperature. However, if E. edulis presents a mechanical structure that hinders water penetration, as mentioned by other authors [6], heated water at $80^{\circ} \mathrm{C}$ does not provide its rupture. Better anatomic and germination studies are required to clarify the seed structure and provide methods to improve the germination rates of E. edulis. Cursi \& Cicero [5] found that $E$. edulis fruits, when immersed during 20 minutes on water at $40^{\circ} \mathrm{C}$, presented higher germination. While exposure to $55^{\circ} \mathrm{C}$ water before processing seems to be harmful to embryos. Our results conflict with this information. However, the consistent variations observed in germination indexes provided by seeds' origin, and environmental conditions adopted during the experiment could also be responsible for this kind of discrepancies between studies.

A

B

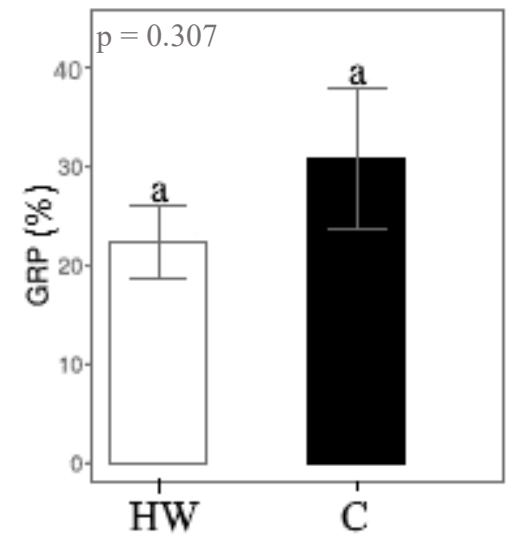

Treatment

Treatment

Figure 4. E. edulis germination indexes according to seed processing treatments: Heated water (HW) and control (C). A - Germination Proportion (GRP), B - Mean germination time (MGT). Lowercase letters represent statistical differences adopting $\mathrm{p}<0.01$. Error bars present the standard error mean.

The cumulative germination pattern was also very similar between the treatments (Figure 5), emphasizing that this procedure does not substantially modify seed germination. Besides that, adopting a heated water procedure makes the removal of fruit external parts easier, and it seems to not substantially affect the seedling 
production seeking commercial could be used in the seedling proposes, which was also production context, without major mentioned in previous studies [5]. harmful effects.

Therefore, this kind of procedure

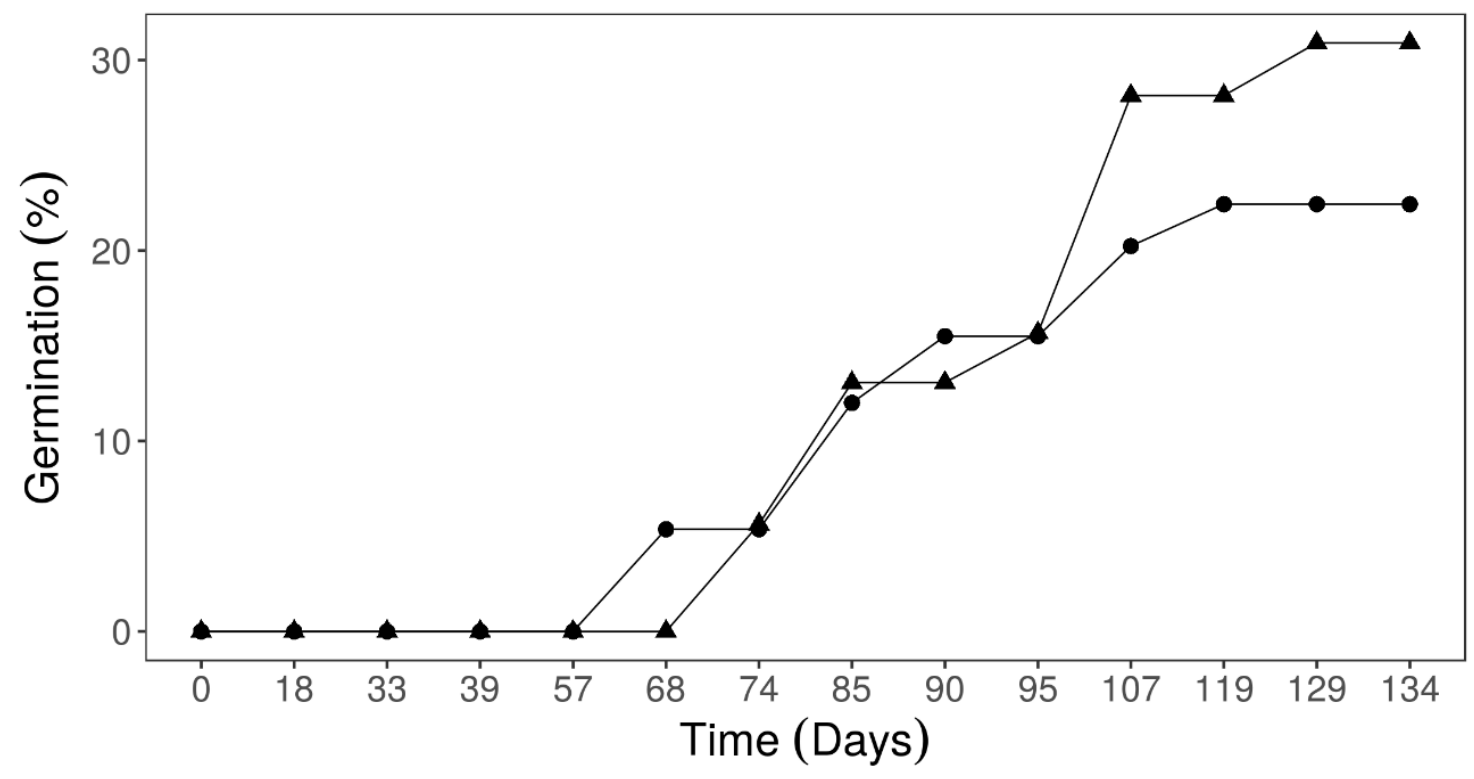

Figure 5. Cumulative germination of E. edulis according to seed processing. Heated water $(\bullet)$ and Control group $(\boldsymbol{\Delta})$.

\section{Open-field and greenhouse production process}

Analyzing the production limits of growth [37]. The results also process of open field and emphasize that the greenhouse greenhouse, some variations were promotes faster and better significant to all the analyzed germination of $E$. edulis seeds. parameters, except for the Greenhouses usually promote a uncertainty and synchronization stable temperature, controlled index (Fig. 6). The greenhouse moisture, and less susceptibility to process provided better results at all environmental conditions. This indexes, the required time to group of features favors seedling germination and stabilization were emergence. Contrasting to the open faster, and the germination rate was field, the greenhouse promoted significantly greater, providing better exploitation of a seed lot. The greenhouse production process has been recognized to notably optimize plant production and reduce the both better germination rate and reduced time required for germination, favorable aspects seeking commercial seedling production. 


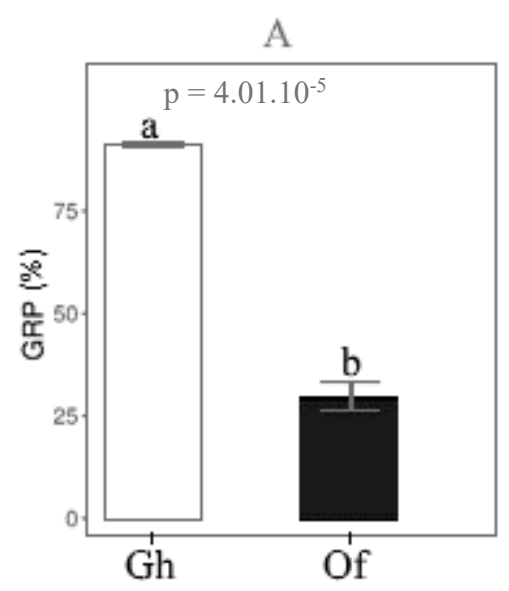

Sowing method

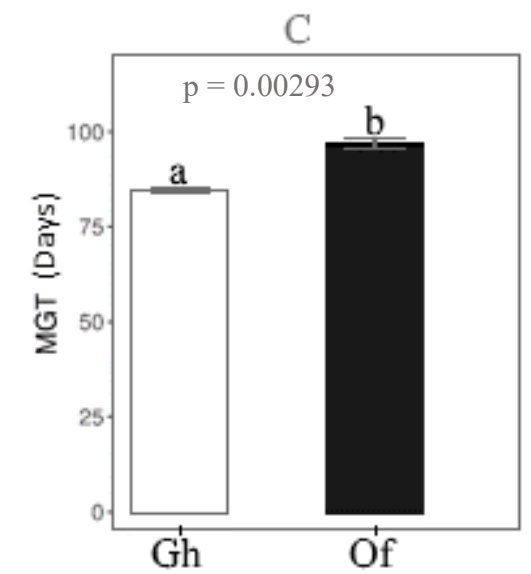

Sowing method

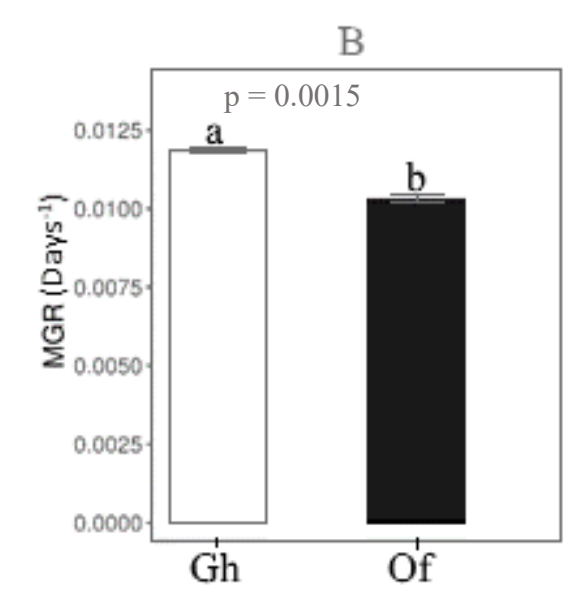

Sowing method

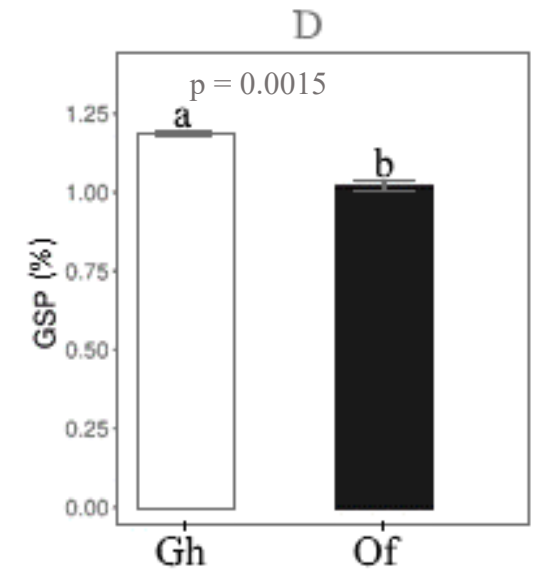

Sowing method

Figure 6. E. edulis germination indexes according to different sowing methods, greenhouse (Gh), and Open-field (Of). A - Germination Proportion (GRP), B - Mean germination rate (MGR), C - Mean germination time (MGT), and D - Germination speed (GSP). Lowercase letters represent statistical differences adopting $p<0.01$. Error bars present the standard error mean.

The cumulative seed viability of seeds affecting germination pattern was germination and seedling substantially distinct (Fig. 7). It is development [2], [38]. Open-field already recognized that controlled also propitiates higher sunlight conditions favor better expression exposure and less water provision. of the germinative capacity of seed Water availability seems to be a lots, while in the open field, the crucial aspect of $E$. edulis seed attack of animals and also development. Earlier life stages are microorganisms, reduces the the least tolerant to water deficit, 
and the resistance seems to establishment. Reduced gradually increase with age [10]. performance of germination the Thus, the lesser water provision in open-field technique has also been open-field treatment could be the reported in other species from main factor to reduce germination Fabaceae [23]. Besides that, some performance. In an ecological authors affirm that even when this approach, open-field treatment also species is more exposed to provides environmental conditions environmental conditions, E. edulis relatively closer to natural or plays the role of pioneer species, anthropic disturbed areas [23]. being the first mesophytic species to Providing a set of environmental conquer disturbed environments conditions that do not favor seedling [8].

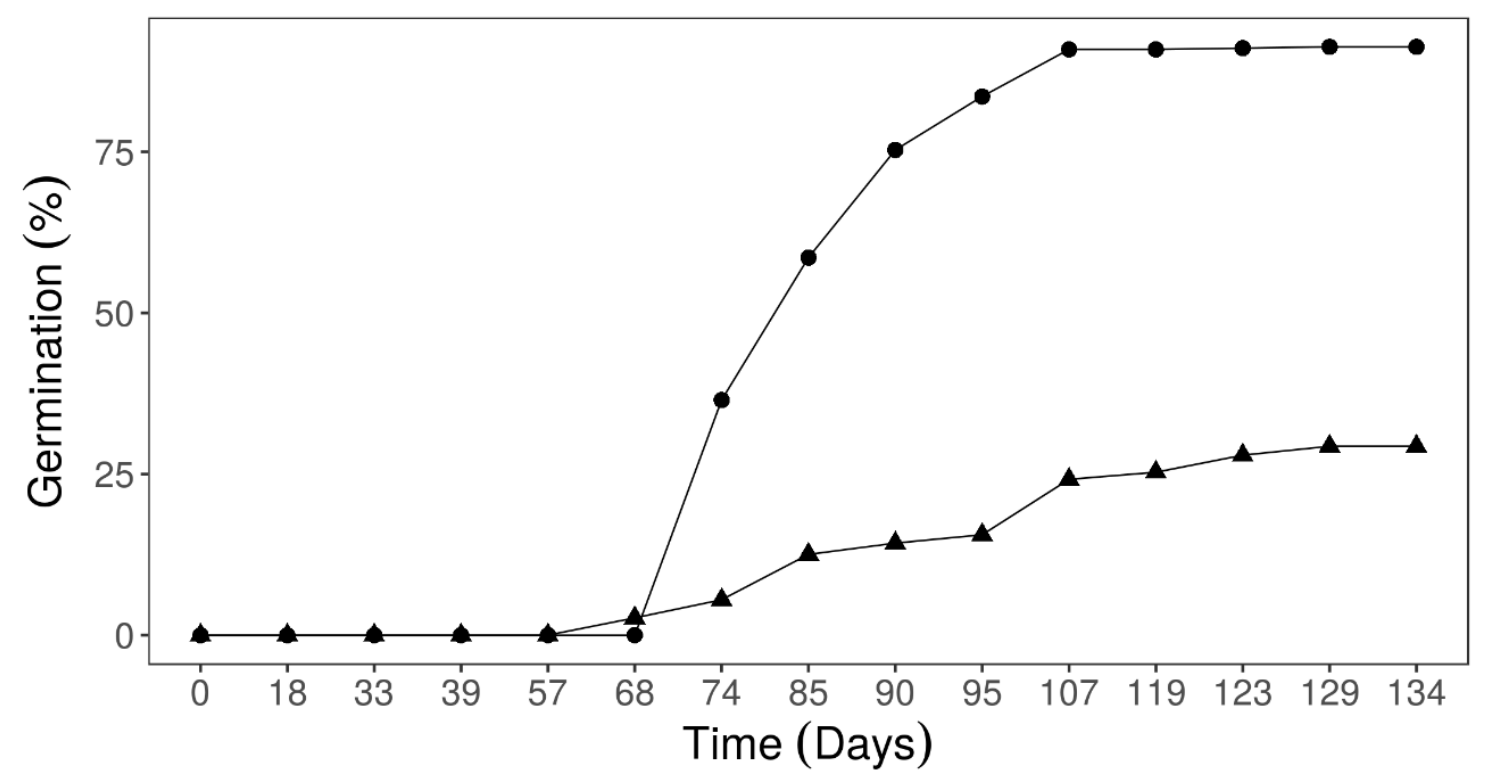

Figure 7. Cumulative germination of $E$. edulis according to the seed production process: Greenhouse $(\bullet)$ and Open-field $(\boldsymbol{\Delta})$ production methods.

Even though the open-field production method does not provide the best environment for germination, this method is adopted for some crops because it requires less electricity and labor when compared to the greenhouse method [39], and facilities maintenance is cheaper than greenhouses, reducing the production cost [23]. Sometimes this practice is also used to recover degraded areas [38]. However, the cost-benefit ratio needs proper evaluations for further studies.

\section{CONCLUSION}

The different parent populations seem to influence the germination rate, mean time to germination, and germination 
speed, but did not affect the uncertainty and synchrony indexes.

Water heated at $80^{\circ} \mathrm{C}$ did not affect germination indices, indicating that it is a feasible method for seedling production. The most profitable method for $E$. edulis seed germination is the greenhouse production method since it provides the best results, associated to germination, speed, and time required for germination.

\section{ACKNOWLEDGMENTS}

I would like to appreciate Secretaria do Verde e Meio Ambiente of São Paulo due to its trainee programs. In addition, the workgroup of Harry Blossfeld. Also Rafaela C. Perez, Juliana de Lemos, and Caio G. Tavares Rosa, due to their consistent scientific support and encouragement.

\section{REFERENCES}

[1] A. C. S. De Andrade and T. S. Pereira, "Comportamento de armazenamento de sementes de palmiteiro (Euterpe edulis Mart.)," Pesqui. Agropecu. Bras., vol. 32, no. 10, pp. 987-991, 1997.

[2] G. P. Calvi and F. C. M. Piña-Rodrigues, "Fenologia e produção de sementes de Euterpe edulis - Mart em trecho de floresta de altitude no município de Miguel Pereira-RJ," Rev. Univ. Rural. série Ciências da Vida, vol. 25, no. 1, pp. 33-40, 2005.

[3] J. Z. da Silva and M. S. dos Reis, "Fenologia reprodutiva e produção de frutos em Euterpe edulis (Martius)," Cienc. Florest., vol. 28, no. 1, pp. 295-309, 2018, doi: 10.5902/1980509831655.

[4] E. Egidio, L. Valente, M. F. Paulino, E. Detmann, and S. De Campos, "Euterpe edulis seed germination parameters and genotype selection," Acta Sci., vol. 42, no. e42461, pp. 417-424, 2020, doi: 10.4025/actascianimsci.v35i4.21143.

[5] P. R. Cursi and S. M. Cicero, "Fruit processing and the physiological quality of Euterpe edulis martius Seeds," J. Seed Sci., vol. 36, no. 2, pp. 134-142, 2014, doi: 10.1590/2317-1545v32n2847.

[6] M. L. A. Bovi and M. Cardoso, "Germinação de sementes de palmiteiro (Euterpe edulis Mart.)," Bragantia, vol. 35, pp. XXIX-XXXIV, 1975, doi: 10.1590/S0006-87051975000100028.

[7] R. Illenseer, M. Terezinha, and S. Paulilo, "Crescimento e eficiência na utilização de nutrientes em plantas jovens de Euterpe edulis mart . Sob dois níveis de irradiância, nitrogênio e fósforo," Acta Bot. 
Brasilica, vol. 16, no. 4, pp. 385-394, 2002.

[8] H. Lorenzi, Árvores brasileiras: manual de identificação e cultivo de plantas arbóreas nativas do Brasil. Nova Odessa: Plantarum, 2002.

[9] A. G. Pereira, "Distribution of Euterpe edulis in the Atlantic Forest reveals different levels of genetic variability: implications for conservation," Universidade federal do espírito santo, 2019.

[10] R. M. De Oliveira, A. Albano, V. L. Engel, J. R. de S. P. Passos, and L. F. R. de Almeida, "Water deficit responses of Euterpe edulis Martius seedlings at different growth stages Respostas," Sci. For., vol. 45, no. 113, pp. 101-108, 2017, doi: dx.doi.org/10.18671/scifor.v45n113.09 101.

[11] C. C. Martins, M. L. A. Bovi, J. Nakagawa, and C. G. Machado, "Secagem e armazenamento de sementes de Juçara," Rev. Árvore, vol. 33, no. 4, pp. 635-642, 2009.

[12] M. P. Martins-Corder and C. W. Saldanha, “Germinação de sementes e crescimento de plântulas de diferentes progênies de Euterpe edulis Mart.," Rev. Árvore, vol. 30, no. 5, pp. 693-699, 2006.

[13] S. Kanashiro, F. F. A. Aguiar, P. Giampaoli, R. C. S. Ribeiro, and A. R. Tavares, "Effects of light, temperature and mesocarp on germination of juçara-palm (Euterpe edulis) seeds," Acta Hortic., vol. 1249, pp. 4750, 2019, doi: 10.17660/ActaHortic.2019.1249.9.

[14] F. C. M. Piña-Rodrigues, J. M. Freire, P. S. dos S. Leles, and T. B. Breier, Parâmetros Técnicos para a produção de Sementes Florestais, 1st ed. UFRRJ: Seropédica, 2007.

[15] J. P. de Maçaneiro, L. Z. Oliveira, P. V. Eisenlohr, and L. A. Schorn, "Paradox between species diversity and conservation: A subtropical Atlantic forest reserve in Brazil has similar tree species diversity to unprotected sites in the same region," Trop. Conserv. Sci., vol. 9, no. 4, 2016, doi: 10.1177/1940082916668011.

[16] M. S. Carvalho, L. R. Noia, M. F. da S. Ferreira, and A. Ferreira, “DNA of high quality isolated from the cortex of Euterpe edulis Mart. (Arecaceae)," Cienc. Florest., vol. 29, no. 1, pp. 400-406, 2019, doi: 10.5902/1980509824130.

[17] A. C. Vibrans, A. L. De Gasper, P. Moser, L. Z. Oliveira, D. V. Lingner, and L. Sevegnani, "Insights from a large-scale inventory in the southern Brazilian Atlantic Forest," Sci. Agric., vol. 77, no. 1, pp. 1-12, 2020, doi: 10.1590/1678-992x-2018-0036.

[18] A. A. Carpanezzi and L. C. T. Marques, "Germinação de sementes de jutaí-açu (Hymenaea courbaril L.) e de jutaí-mirim (H.parvifolia Huber) escarificadas com ácido sulfúrico comercial," in EMBRAPA CPATU, Circular T., Belém: EMBRAPA-CPATU, 1981, p. 15.

[19] J. A. P. Fowler and A. Bianchetti, "Dormência em sementes florestais," 
Embrapa Florestas, no. Documentos 40, pp. 1-27, 2000.

[20] L. Pupin, V. da S. Santos, J. P. dos Santos Neto, D. O. De Fusco, and G. $\mathrm{H}$. de A. Teixeira, "Is the bioaccessibility of minerals affected by the processing steps of juçara fruit (Euterpe edulis Mart.)?," LWT - Food Sci. Technol., vol. 91, pp. 14-25, 2018, doi: 10.1016/j.Iwt.2018.01.024.

[21] M. C. de Oliveira et al., Manual de Viveiro e Producao de Mudas Espécies Arboreas Nativas do Cerrado. Brasília: Rede de Sementes do Cerrado, 2016.

[22] E. Costa, K. G. Lopes, F. F. da S. Binotti, E. D. C. Binotti, and C. Dalastra, "Technologies for jatoba seedling formation," Floresta e Ambient., vol. 26, no. 1, pp. 1-8, 2019, doi: 10.1590/2179-8087.008415.

[23] L. Regnier, "Influence of mechanical scarification and open-field sowing procedure over Cassia ferruginea germination process," 2020.

[24] L. de L. P. Regnier, "Peltophorum dubium fruit processing influence on germination," Rev. Científica Multidiscip. Núcleo do Conhecimento, vol. 09, no. 10, pp. 112-120, 2019.

[25] C. Nogueira and P. H. S. Brancalion, Sementes e mudas: guia para propagação de árvores brasileiras. São Paulo: Oficina de textos, 2016.

[26] M. A. Ranal and D. G. de E. Santana, "How and why to measure the germination process?," Rev. Bras. Botânica, vol. 2, pp. 1-11, 2006, doi: 10.1590/S0100-84042006000100002.

[27] L. G. Laboriau, "A germinação das sementes," Programa Regional de Desenvolvimento Científico e Tecnológico Série de Biologia, 1983.

[28] F. Lozano-Isla, O. E. Benites-Alfaro, and M. F. Pompelli, “GerminaR: An $\mathrm{R}$ package for germination analysis with the interactive web application 'GerminaQuant for R,'” Ecol. Res., vol. 34, no. 2, pp. 339346, 2019, doi: 10.1111/1440-1703.1275.

[29] R Core Team, "R: A Language and Environment for Statistical Computing." R Foundation for Statistical Computing, Vienna, 2019.

[30] M. A. Ranal, D. G. D. E. Santana, W. R. Ferreira, and C. Mendesrodrigues, "Calculating germination measurements and organizing spreadsheets," Rev. Bras. Botânica, vol. 32, no. 4, pp. 849-855, 2009.

[31] D. B. De Carvalho and R. I. N. De Carvalho, "Qualidade fisiológica de sementes de guanxuma sob influência do envelhecimento acelerado e da luz," Acta Sci. - Agron., vol. 31, no. 3, pp. 489-494, 2009, doi: 10.4025/actasciagron.v31i3.585.

[32] T. M. Ribeiro, S. V. Martins, V. M. Lana, and K. de A. Silva, "Survival and intial growth Of Euterpe edulis Mart. seedlings transplanted to gaps and understory in semideciduous forest, Viçosa, MG," Rev. Árvore, vol. 35, no. 6, pp. 1219-1226, 2011.

[33] A. C. S. de Andrade, M. B. Loureiro, A. D. O. Souza, F. N. Ramos, and A. P. M. Cruz, "Reavaliação do efeito d substrato e da temperatura na 
germinação de sementes de palmiteiro (Euterpe edulis Mart.)," Rev. Árvore, vol. 23, no. 3, pp. 279-283, 1999.

[34] W. E. Finch-Savage and G. W. Bassel, "Seed vigour and crop establishment: Extending performance beyond adaptation," J. Exp. Bot., vol. 67, no. 3, pp. 567-591, 2016, doi: 10.1093/jxb/erv490.

[35] D. Ferraz, W. P. Ramalho, and L. S. R. Vale, "Methods for overcoming dormancy and seed storage of enterolobium contortisiliquum," Acta Sci. - Agron., vol. 41, no. 1, pp. 1-7, 2019, doi: 10.4025/actasciagron.v41i1.42602.

[36] B. L. Aliero, "Effects of sulphuric acid, mechanical scarification and wet heat treatments on germination of seeds of African locust bean tree, Parkia biglobosa," African J. Biotechnol., vol. 3, no. 3, pp. 179-181, 2004, doi: 10.5897/ajb2004.000-2031.

[37] W. R. Jarvis, "Managing Diseases in Greenhouse Crops," Am. Phytopathol. Soc., vol. 73, no. 3, pp. 190-194, 1989.

[38] V. L. Mattei and M. D. Rosenthal, "Semeadura direta de canafístula (Peltophorum dubium (Spreng.)Taub. no enriquecimento de capoeiras," Soc. Investig. florestais, vol. 26, no. 6, pp. 649-654, 2002.

[39] B. Ozkan, C. Fert, and C. F. Karadeniz, "Energy and cost analysis for greenhouse and open-field grape production," Energy, vol. 32, no. 8, pp. 1500-1504, 2007, doi: 10.1016/j.energy.2006.09.010. 